\title{
Does Microcredit Bring the Women into Economic World: Evidence from Bangladesh
}

\author{
Mohammad Abdul Matin Chowdhury'1, Marhanum Che Mohd Salleh², \\ Sylva Alif Rusmita ${ }^{3}$, and Puji Sucia Sukmaningrum ${ }^{3}$ \\ ${ }^{1}$ Master student in Islamic Finance, Department of Finance, Kulliyyah of Economics \& \\ Management Sciences, International Islamic University Malaysia \\ ${ }^{2}$ Assist. Professor at Department of Finance, Kulliyyah of Economics \& Management Sciences, \\ International Islamic University Malaysia \\ ${ }^{3}$ Lecturer at Department of Islamic Economics, Faculty of Economics and Business, Universitas \\ Airlangga
}

\section{Abstract}

The empowerment, entrepreneurship and education are the most imperative issues among women to develop the country. Micro credit is one of the effective tools to eradicate poverty among poor people through enhancing women empowerment, enhancing the entrepreneurial activities and improving education level for both men and women. It has initiated the schemes to encourage entrepreneurial activities along

Received: 10 February 2019

Accepted: 14 March 2019

Published: 28 March 2019

Publishing services provided by Knowledge E

(c) Mohammad Abdul Matin Chowdhury et al. This article is distributed under the terms of the Creative Commons

Attribution License, which permits unrestricted use and redistribution provided that the original author and source are credited.

Selection and Peer-review under the responsibility of the ICIEBP Conference Committee. with developing education level and enhance the women empowerment in the country. The main goal of this research is to inspect the improvement of women empowerment, evaluate the development of entrepreneurship and the education level among micro credit borrowers in Bangladesh. There are two hundred and thirty respondents were participated in this research. The data were analyzed by the descriptive and multiple linear regression analysis. The results found that the women empowerment slightly develops even though it is not significant statistically whereas the entrepreneurship and education are negatively associated with micro credit programs. This research influences the micro credit institutions to develop and focus on the application of loaned amount by borrowers to affect significantly on women empowerment, entrepreneurial activities and education level. Finally, this research is also merits the government to widen the facilities and lessen the hardship on micro credit institutions and encourages the policy in Bangladesh.

Keywords: Micro credit, women entrepreneurship, women empowerment, poverty alleviation, Bangladesh

\section{Introduction}

The entrepreneurship and women empowerment are the important issues for any economy especially for the developing countries where it affects the whole economy. 
for developed economy as well. Entrepreneurship and empowerment are not only enhancing the quality of life, also increase the standard of live, develop the condition of family and the scenario of the economy. As a result, the development in the rate of entrepreneurship and empowering women lead to effective tool to eradicate poverty and boost the economy. The importance of women empowerment can be identified from the United Nations Millennium Development goals which indicated as "promote gender equality and women empowerment" (The Millennium Development Report, 2006). In developing countries like Bangladesh initiated the Micro credit system to improve in these areas. Micro credit is set to help poor people by providing small loan whereby they get rejected from conventional bank due to lacking of assurance. Hence, through micro credit facility, financial assistance is offered to the poor to enhance entrepreneurial activities (through businesses), family income, and living standards. Since the micro credit loan was started to offer only towards women. Small businesses such as handicrafts, poultry etc. was taken by women whereby they found themselves in an effective bread winner for the family. Consequently, the women became selfindependent and enforce them to come out for work and manage their living and contribute in the family, they received the courage to take decision for the family welfare as well as involve in community activities and politics. Besides initiating business by themselves, the women enforce their spouse to involve in workforce to manage the weekly payment of the loan which let people to join in workforce, as a result, the power of decision making and employment rate tremendously increased. These activities enable them to have more power, capability, voice to participate in decision making and social status in the family as well as in the community.

However, these developments have merely recognized in the real social life. Women entitled to receive small amount from the MFIs, mostly men enforced them to take it. As a result, most of the women do not get the opportunity to use the loan for entrepreneurial work. Practically, men are still dominating in developing country where women obedient to their partner due to lack of self-confidence and their ability to engaging in the business activities. Besides, the education level for the women have found inadequate to utilize the entrepreneurial activities to generate more profit and challenge themselves into economic world. Therefore, women empowerment is not escalating based on theory of the women empowerment by micro credit along with effective entrepreneurial activities. This study aims to evaluate the impact of micro credit towards women entrepreneurship and the empowerment. We investigated the impact of micro credit towards the increasing entrepreneurship rate as well the empowering women in the context of Bangladesh by representing three questions. First, is there any 
significant impact of micro credit towards the increasing entrepreneurship rate? Second, is there any effectiveness of micro credit towards women empowerment in Bangladesh? Lastly, does the education/training plays any role for the women borrowers?

\section{Literature Review}

Entrepreneurship enables the citizens to create their own luck by starting business to manage their own income and social benefits. Women empowerment is another vital issue for any developing country. In developing country such as Bangladesh where mostly men dominate the economy as well as the family bread winning activities. According to Dr Amartya Sen (Nobel laureate), women empowerment is the most important factor to create a developed country. He also mentioned that Bangladesh has tremendously brought the positive changes in women empowerment (the $67^{\text {th }} \mathrm{UN}$ General Assembly. 2012). Micro credit started the effective strategy to empower women by offering small loans only towards women entrepreneurs which allowed them to work efficiently without having pressure from spouse. Micro finance provide the credit in smoothen way to create an effective improvement in the living standard of poor people (Karlan \& Zinman, 2011). Micro finance is an example that imitates the facility of credit and small loans to poor people to enhance their earnings (Awojobi \& Bein, 2011). The authors also indicated that it includes the utilization of funds and distribution of micro credit to the financially active poor, which deliver the employment and sustainability to move upward the living standard in a community. It is supported by Langford, A. \& Evaluator (2010) who found from the interview and survey that OCLF (The Ottawa Community Loan Fund, Canada) programming subsidizes to enhanced relationship between clients and financial institutions which creates credit ratings for individuals and new opportunities for business enlargement. The authors also added that this relationship enhancing the creation of new bank accounts to access credit for the expansion of businesses and it also helped individuals to gain employment at higher wages and helped business to create new employment opportunities. The MFIs are playing an important role to reduce poverty by encouraging poor people through the entrepreneurial activities and creating employment by making micro credit accessible among the poor people in rural area. As a result, the poor people are able to change their lives by engaging themselves into entrepreneurial activities along with enforcing the family members to join in workforce to settle the repayment which boosting the economy across the country. In this scenario, the MFIs are playing a vital role for the developing countries in order to enhancing the living standards of poor people, encouraging women to become entrepreneur which 
directly lead them to be important member of the family and also breadwinner in some families (Khan \& Dewan, 2017; Venittelli, 2017).

There are many researchers found the positive impact of effectiveness of micro finance on borrower's life whereby several researchers found negative evidence as well. Micro finance has improved the living standard in developing countries by offering small loans towards poor people to invest in small business, agriculture, entrepreneurial activities. Micro finance has spread out the arena in the rural areas where the people were struggling financially that led them to lack of education, unavailability of knowledge in health and food security. The power and status of women were considered narrowly in family few decades earlier. The women were seen as housewives and men dominated community around the developing countries. Apart from education \& globalization, micro finance has significantly brought the effect on women's power and social contribution as well economic development and independence. Micro credit has played an important impact on the increase of socio-economic status, sovereignty for life choices; improve the women position in family/society, and positive slant towards child development in India (Modi et al 2014). Indeed, men and women have equal rights to make decisions for the welfare and leading family taking the form of pursuit of cooperation.

Households that microcredit helped to raise the females' wellbeing and perhaps to decrease male prejudice in well-being consequences, predominantly in deprived households (Mahmud, 2003). It is very important for the entrepreneurship to have minimum knowledge in utilizing the financial activities in a manner to reduce cost and increase the productivity. The micro-e entrepreneurship program (Financial Literacy) helped to reduce the debt by the borrowers after going through training in Chile (Martínez A. \& Puentes, 2017). MFls training program for the borrowers develop and identified the existing skills and capability of women to utilize through startup business which lead them to become self-independent as well as enhance the living standards and health care (Babiker et al, 2017; Choudhury, Das, \& Rahman, 2017; Santha \& Lazarus, 2016). In this scenario, MFIs in developing countries should focus on some trainings and events to promote entrepreneurs by imposing opportunities and ways to start business with small amount. It may be a strategy for the MFis to promote their schemes. However, the author has found merely a narrow straight outcome in growing females' entrée to choice increasing resources through microcredit program participation in Bangladesh. Through the availability of capital for investing in entrepreneurial activities, employment, by taking loans from microfinance, the gender inequality has reduced dramatically in developing countries such as Bangladesh, Pakistan, and India etc. However, Awaworyi, 
S. (2014) didn't find any positive impact of microfinance on women empowerment in his empirical literature, by conducting Meta-Analysis, Multivariate meta regression analysis on five measures are mobility, decision making power, awareness and women's assets and control over finance in developing countries. In align, Amin M. A., et al. (2013) also mentioned in his qualitative research that Micro credit is not adequate to empower women in the perspective of Bangladesh individually whereby it is dominated by society and culture in regards of gender distinguished outlook towards their lives. Bangladesh requires a wide-ranging change at all levels of human functioning including social, economic, political, religious, psychological and cultural practices. Microfinance in Bangladesh has reduced the vulnerability of the poor through smoothing consumption and limiting the effects of seasonal shortfalls in income, building assets to absorb shocks, empowering female borrowers within their households and community, bringing in changes in the areas of education, sanitation etc (Zaman, 2004).

Micro credit can significantly expand the household's wellbeing like revenue and ingesting in china ( $\mathrm{Li}, 2010)$. Micro credit has a momentous effect on five diverse extents of women empowerment reaching from economic safety to consciousness of communal matters,.diverse proportions of women empowerment reaching from economic safety. The micro credit program provided the chance to undertaking into self-employment to borrowers with low incomes. Micro credit has empowered and strengthened borrower's self-confidence as well as it also enhanced the women empowerment in Brazil (Gutberlet, 2009). He also added that micro finance along with collective commercialization is essential tools within social and solidarity economy. Education is the important part for the development of any nation as well as individual. The education among micro credit borrowers help to utilize the loans in way to generate more profit by engaging entrepreneurial activities as well as enhance the empowerment of women across the country (Al Mamun, Saufi, \& Ismail, 2016; Choudhury, Das, \& Rahman, 2017). The micro credit availability, entrepreneurial training and knowledge and motivation to start business impact the performance of micro entrepreneurs positively in Malaysia (Al Mamun et al., 2016). Micro credit alone is not sufficient to alleviate poverty from developing countries (Quach, 2017). There are many other tools required to be implemented to alleviate poverty such as encourage to engaged poor people in to entrepreneurial activities as well as ensuring equal rights among men and women. Throughout the literature review, it is acknowledged that there is no research has conducted to identify the specific improvement in entrepreneurship and education level by the micro credit schemes in Bangladesh. As, result, this study has taken these two variables along with 
women empowerment as independent variables and the micro credit as dependent variable.

\section{Methodology}

The primary data has been initiated from various areas of Bangladesh for this paper. The questionnaires were distributed in between May and June, 2016. All data was received through surveys. The survey was conducted towards the women entrepreneurs that involve with micro credit loan through an individual person for each area. There were 250 women answered the questions completely in the survey from four areas; Chittagong, Gazipur, Dinajpur, Feni. In this paper, the descriptive analysis used to identify the mean value for the respondents perception and multiple regression models were used to achieve the objectives of this study.

\section{Result}

Based on the descriptive analysis results, micro credit is unable to satisfy the borrowers in broad range. The level of satisfaction among the woman borrowers on micro credit is observed ranked from 2.0304 to 3.5488 and the average is 2.966 whereas standard deviation is 0.79871 . Most of the women are not satisfied with the interest rate that is imposed by micro finance institutions which align with (Khan \& Dewan, 2017). The least mean value of interest rate is 2.0304 . Therefore, the borrowers seem to have a less satisfaction altitude towards micro finance institutions in Bangladesh. However, the results from the average mean value (2.966) concluded that borrowers are quite satisfied with micro credit system and its administration. Micro credit system has not significantly satisfied the borrowers but it has attracted them to engage with the system due to availability of credit and the easy access of it. The mean value for women empowerment is ranked between 3.0830 and 4.0734 . It can be said that women's' opinion and thought were generally accepted and considered by the society after they engaging with micro credit loan and they can make decision without any interference by external parties. However, they are neutral (no agree or disagree) with regards to the freely participation in judiciary duties in local community disputes (least mean value of 3.0830). As the average mean value is 3.6644 , the borrowers seem to have a sensible improvement in women empowerment through the micro credit involvement. Based on the descriptive analysis results, the level of Entrepreneurship among borrowers is observed based on the mean value ranked from 2.9174 to 3.3565 and the average mean 
value is 3.13. In this context, it is regards that majority of the woman borrowers were neutral on the statements of entrepreneurship given in the questionnaire. Because of this value represents neutral response from the respondents, it indicates that the woman are neither agree nor disagree that micro credit loan has assist them towards business activities which indirectly contributes to the enhancement of the local economy. Territory and technical education are seemed to be important and necessity for the women to run their business smoothly and effectively. The level of education among borrowers is observed based on the mean value ranked from 2.7304 to 3.6696 . However, they are not aware of affording part time studies for personal development purposes. In general, the borrowers seem to have a standard development in Education after taking loan. The education level slightly increased and the interest of having skilled trainings among borrowers seen to be highlighted to utilize the credit for entrepreneurial activities effectively.

TABLE 1: Descriptive Analysis.

\begin{tabular}{|l|l|c|c|}
\hline No & Variable & Mean & Standard Deviation \\
\hline 1 & Micro Credit (CSA) & 2.966 & 0.79871 \\
\hline 2 & Women Empowerment (WE) & 3.6644 & -0.763692 \\
\hline 3 & Entrepreneurship (ENT) & 3.1326 & 1.25096 \\
\hline 4 & Education (EDU) & 3.1174 & 1.2446675 \\
\hline
\end{tabular}

\subsection{Correlation and regression analysis}

From the table 2, the Pearson correlation coefficient between dependent variable which is micro credit (CSA) and independent variables which are woman empowerment, entrepreneurship, and education (WE, ENT, EDU) presents the negative correlation at $1 \%$ of significance. According to the result from multiple linear regression model, it indicates that the micro credit does not associate the women empowerment, entrepreneurship and education level of borrowers.

TABLE 2: Correlation analysis.

\begin{tabular}{|l|l|c|c|c|}
\hline & & WE & ENT & EDU \\
\hline CSA & Pearson Correlation & -0.035 & -0.546 & -0.496 \\
\hline \multicolumn{1}{|c|}{ Sig. (1-tailed) } & 0.299 & 0.0000 & 0.0000 \\
\hline
\end{tabular}

Equation: the estimated linear regression

$$
Y=a+b \times 1+c \times 2+d \times 3
$$




$$
\mathrm{CSA}=3.063+0.054(\mathrm{WE})-0.213(\mathrm{ENT})-0.102(\mathrm{EDU})
$$

From the regression analysis (table 3), it presents that ENT and EDU significantly affect the CSA at $5 \%$ level of significance even the correlation negatively associated. however, WE positively affect the dependent variable CSA whereas the p-value is higher than $5 \%$. As a result, it can be concluded that the variables ENT and EDU have the high negative impact compare to other variable WE.

TABLE 3: Coefficients.

\begin{tabular}{|c|c|c|c|c|c|c|}
\hline \multicolumn{2}{|c|}{ Model } & \multicolumn{2}{|c|}{ Unstandardized Coefficients } & \multirow{2}{*}{$\begin{array}{c}\text { Standardized } \\
\text { Coefficients } \\
\text { Beta }\end{array}$} & \multirow[t]{2}{*}{$\mathrm{t}$} & \multirow[t]{2}{*}{ Sig. } \\
\hline & & B & Std. Error & & & \\
\hline \multirow[t]{4}{*}{1} & (Constant) & 3.063 & .150 & & 20.371 & .000 \\
\hline & WE & .054 & .041 & .073 & 1.303 & .194 \\
\hline & ENT & -.213 & .047 & -.412 & -4.580 & .000 \\
\hline & EDU & -.102 & .050 & -.186 & -2.044 & .042 \\
\hline
\end{tabular}

According to the descriptive and regression analysis, it is found that micro credit has failed to satisfy borrowers in terms of services. It can be articulated that the MFIs mostly focused on enhancing the credit accessibility rather than focusing on utilization credit by the borrowers. As a result, the impact cannot be acquired by the borrowers widely. The descriptive analysis result also identified that woman empowerment has improved very steadily by the micro credit. However, regression analysis identified the insignificant correlation between micro credit and women empowerment. The reason for the less development in woman empowerment by the micro credit scheme is the lack of education and the male domination in the community. Even though, the micro credit mostly loan out only to women but generally men associate their spouse to receive it. As a result, women merely have the rights to utilize the amount according to their own entrepreneurial activities.in addition, most of the times; women spend their savings as well existing handicrafts business materials and equipment to repay the credit which reduces the entrepreneurial activities broadly. It is proven by the regression analysis result whereby entrepreneurship is negatively affected by the micro credit. Micro credit facilities aim to encourage entrepreneurial activities among the poor women in Bangladesh. But the lacking of education and training has failed to improve in such activities whereas the poor people engage themselves in productive and effective entrepreneurial endeavor. Those borrowers are having minimum education qualification, they probably having growth in business and satisfy with the services provided by the 
MFIs. Therefore, education plays an important role for all entrepreneurs in order to start business effectively and in the manner of generating profit throughout the best productive process and marketing strategy.

According to the regression analysis result, it shows the decline in education level of borrowers those are engaged with micro credit scheme. The result revealed that the education level is not developed and it shows the negative impact on it. It is due to the pressure from the MFIs that created automatically to repay on time. The system has put pressure on borrowers to repay on time and unavailability of default payment which start immediate after issuing credit. As a result, the borrowers start to find the way to make the payment on time which leads them to send their spouse and kids into workforce to manage money. Therefore, they ignored their children's education. Therefore, the results suggest that MFIs should also organize trainings and sharing knowledge programs along with enhance accessibility of credit towards potential entrepreneurs. It is supported by past researches (Babiker et al, 2017; Choudhury, Das, \& Rahman, 2017; Santha \& Lazarus, 2016) mentioned the importance of education and training events are required by MFIs.

\section{Conclusion}

Micro credit is playing a remarkable tool to eradicate poverty in developing countries. It is also consider as blessing for the poor those are not capable to getting loan from the conventional banks. Bangladesh has set an example of successful implementation of micro credit schemes and the feasibility of its success throughout the decades. Micro finance institutions are also contributing the economy growth along with conventional banks by providing small loans to poor people by enabling them to become entrepreneurs and associating the women in order to become self-independent that lead to be powerful and decision maker for the family as well as the community. This paper may help the MFIs to take initiative steps and process to make the micro credit system into effective and value added system to achieve the best efficiency.

This study aims to find the impact of micro credit towards the woman empowerment, entrepreneurship and education level of borrowers. According to the results of the analysis, the study found a slight development in women empowerment where the borrowers are actively participating in political endeavors as well as in development projects and judicial events but the impact is not statistically significant. The results found the negative impact of micro credit in regards of entrepreneurship and education level of borrowers. Based on the findings of this paper, it can be recommended that 
the MFIs should take few steps such as vocational trainings, entrepreneurship trainings, business skills and marketing strategies trainings to enhance the ability of borrowers in order to utilize the credit into generating profit as well the enhance the education level and empower them to participate events and policy making in the community. The policy makers may implement the development and training projects along with MFIs to9 enhance the economic activities across the country. The researchers may investigate further studies to identify the gap between borrowers and MFIs in order to develop the implementation of credit facilities in larger area.

\section{References}

[1] Al Mamun, A., Saufi, R. A., \& Ismail, M. Bin. (2016). Human capital, credit, and startup motives: a study among rural micro-enterprises in Malaysia. Journal of Developing Areas, 50(4), 383-400.

[2] Amin, M. A., Hossain, M. I., \& Mathbor, G. M. (2013). Women Empowerment through Microcredit: Rhetoric or Reality? An evidence from Bangladesh. Multidisciplinary Journal of Gender Studies, 2(2), 1-21. doi:10.4471/generos.2013.22

[3] Attali, J. About Microcredit. Retrieved from www.microworld.org, http://http://www. microworld.org/en/about-microworld/about-microcredit

[4] Awaworyi, S. (2014). Impact of Microfinance on Female Empowerment: A Review of the Empirical Literature. JEL, Monash University; Australia, 21, 1-22.

[5] Babiker, M. H. O., Mohammed, A. S., \& Shawal, M. S. (2017). Assessment of the impact of start-up capital provided by formal sector on female entrepreneurs in Khartoum State, Sudan: Case of Savings and Social Development Bank micro-credit program. Ahfad Journal, 34(2).

[6] Choudhury, A. H., Das, A., \& Rahman, A. (2017). The Effectiveness of Micro-credit Programmes Focusing on Household Income, Expenditure and Savings: Evidence From Bangladesh. Journal of Competitiveness, 9(2), 34-44.

[7] Gutberlet, J. (2009). Solidarity economy and recycling co-ops in Sa o Paulo: microcredit to alleviate poverty. Routledge, Development in Practice. , 15

[8] History of Microfinance. (2016). Retrieved October 22, 2016, from http://www. microfinanceinfo.com, http://www.microfinanceinfo.com/history-of-microfinance/

[9] Karlan, D., \& Zinman, J. (2011). Microcredit in Theory and Practice: Using Randomized Credit Scoring for Impact Evaluation. The American Association for the Advancement of Science, 332(1278), 1-8. doi:10.1126/science.1200138 
[10] Khan, A. H., \& Dewan, H. (2017). Can The Availability of Informal Loans be Detrimental to Microloan Repayment?? Some Empirical Evidence from Bangladesh. Journal of Developing Areas, 51(4), 347-359.

[11] Khandker, S., \& Hassan Zaman, H. Z. (2016, February 26). The Impact of Microfinance. www.thedailystar.net, pp. 1-2

[12] Langford, A., \& Evaluator (2010). Evaluating the Social Impact of the OCLF/Alterna Community Micro Loan Program. Carleton Centre for Community Innovation.

[13] Li, x. (2010). an empirical analysis of microcredit on china rural household. lincoln university, 262.

[14] Martínez A., C., \& Puentes, E. (2017). Micro-entrepreneurship Debt Level and Access to Credit: Short-Term Impacts of a Financial Literacy Program. European Journal of Development Research, 1-17.

[15] Mahmud, S. (2003). Actually how Empowering is Microcredit? Blackwell Publishing; Development and Change. , 30.

[16] Modi, D. A. G., Patel, K. J., \& Patel, K. M. (2014). Impact of Microfinance Services on Rural Women Empowerment: An Empirical Study. IOSR Journal of Business and Management, 16(11), 1-8.

[17] Quach, H. M. (2017). Does Access to Credit Improve Household Welfare in The LongRun? The Jorunal of Developing Areas, 51(1), 129-142.

[18] Santha, A. M., \& Lazarus, T. P. (2016). An Analysis on the Credit and Repayment Behaviour of Rural Households in Kerala, 103(September), 279-285.

[19] Venittelli, T. (2017). The Impact of Microfinance Institutions on the Informal Credit Market: Evidence from Andhra Pradesh. The European Journal of Development Research, 29(2), 512-531.

[20] Zaman. H. (2004). Microfinance in Bangladesh: Growth, Achievements and lessons. Retrieved October 22, 2016, from http://www.microfinancegateway.org, 